\title{
The puzzle and politics of historical reconstruction
} The case of the rise and development of Christianity and Judaism

$\mathrm{T}$

his essay focuses on the topic of the emergence of Christianity and Judaism as related but distinct religious traditions, as an example of a process of religious and cultural change, which has had an enormous impact on Western and other societies around the world. At the heart of this question lies what appear to be contradictions between normative practices in antiquity and those we know of today, leading us to consider the historical and hermeneutical issue of continuity and change over time; its how, when and why. Rejecting the idea that theological differences between Judaism and Christianity necessitated a 'parting of ways' between them, it is argued that social, political and colonial decision-making was essential to this process, and that, furthermore, a historical focus on institutional realities in the ancient Mediterranean world, including in Jewish society, will challenge many long-held assumptions about the origins not only of Christianity but also of Judaism. The general historical reconstruction offered is then applied to a specific archaeological site, Capernaum, showing how traces of the larger pattern of development from the first to the fifth century CE may be seen in the histories of two buildings in this town.

\section{Introduction: the history and present of Judaism and Christianity}

Addressing issues of religion and cultural change, I have chosen to focus here on the topic of the emergence of Christianity and Judaism as related but distinct religious traditions. At the heart of this question lies what appear to be contradictions between normative practices in antiquity and those we know of today, leading us to consider the intriguing historical and hermeneutical issue of continuity and change over time; its how, when and why. Our question can be rephrased in a very straightforward way: if Jesus was Jewish, why is it that Christians are not Jews? And if Jesus attended synagogue on Sabbaths, why do Christians attend church on Sundays? These deceptively simple questions carry within them great complexity. While modern Christians and Jews have developed their own normative answers to these issues, a historical investigation will reveal that things are not always what they seem to be. Indeed, if we allow history a voice in our contemporary discussions, the past will challenge many long-held assumptions about the origins not only of Christianity but also of Judaism.

One cannot locate a soul without a body: this is true also of religions as they are embodied in institutions; hence, an interesting way to approach the theme of Jewish and Christian origins is to consider the institutions with which we identify the respective religions: the synagogue and the church. The question then becomes: what do we think of when we hear these words, 'synagogue' and 'church'? And why do we think this way? The why question is 


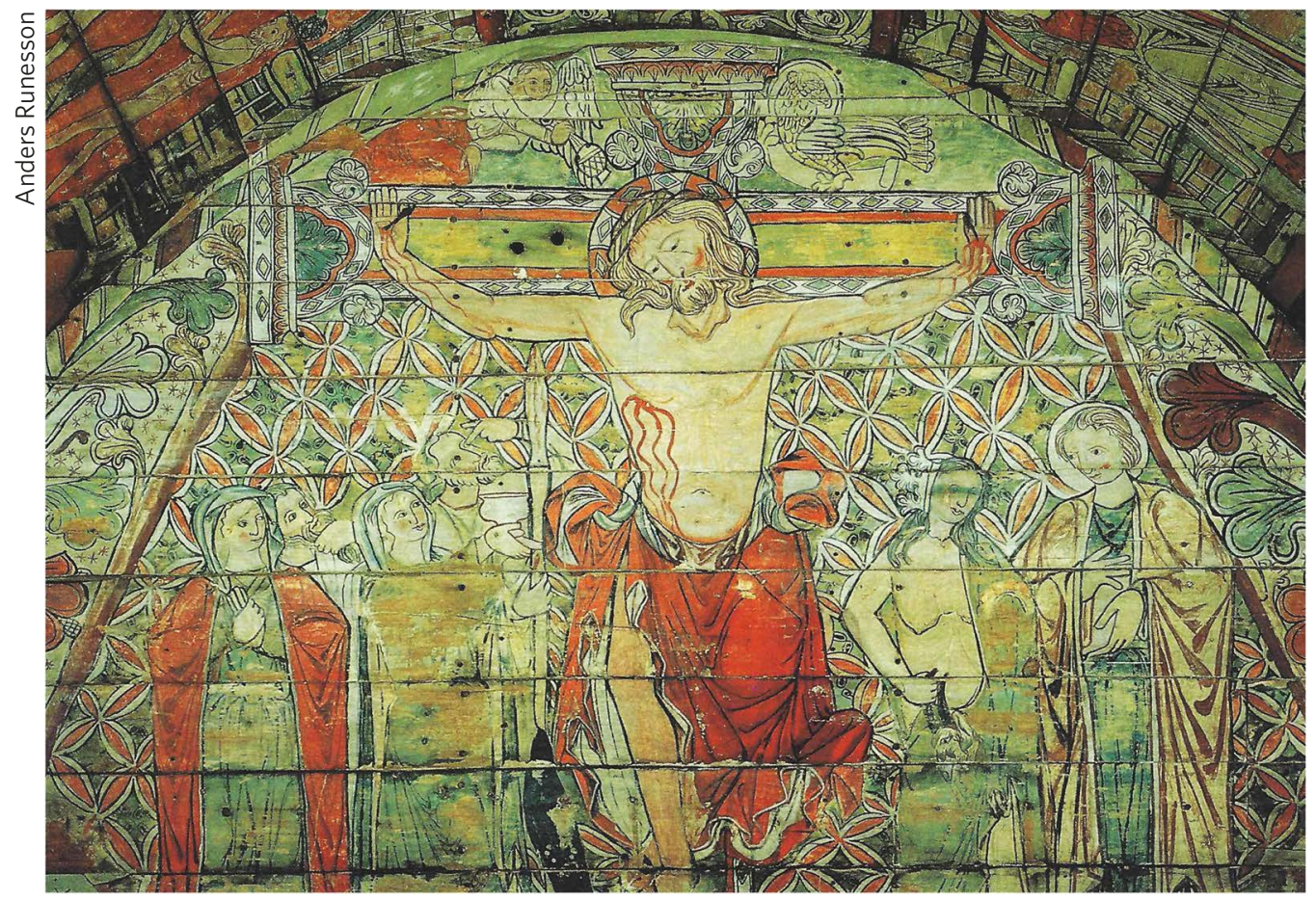

Depiction of Jews and Christians (synagogue and church) through a crucifixion scene in $\AA$ I stave church in Hallingdal, Norway (13th century). Cf. Schreckenberg 1996: Plate 3.

important because the way we think and behave is never the outcome of inescapable developments, as if religion, for example, provided us with a manual with which we could predict the shape of our future lives. Our way of relating to the world around us is rather the result of historical and social processes and choices, most of which we are unaware. One of the first steps in understanding who we are and why we do things the way we do is to study these historical and social processes critically. Indeed, in such study may lie hidden important clues to future ways of forming relationships and interacting, as we actively take responsibility for the shape our society takes.

Looking, then, at our question of the origins of separate Jewish and Christian identities as they are embodied institutionally in synagogue and church, we see that this process of separation did not happen by itself, as if it were an inevitable, theologically driven process (as is often assumed by adherents of these religions). For centuries - in fact, for more than a millennium and a half - Christian ecclesial authorities in Europe worked hard, in literature and art, to establish the church as an institution different from the synagogue; Christianity as something different from Judaism. In art, for example, the synagogue might be depicted as a defeated blind woman, and the church as a victorious queen. ${ }^{1}$ The politics of Christian identity formation has gone further than this, however, as the medieval so-called living crosses show. In such depictions, the life of the church was shown to require the death of the synagogue. ${ }^{2} \mathrm{~A}$ variant of the latter is found also in some Norwegian medieval

1 Schreckenberg 1996: Plate 4.

2 Schreckenberg 1996: 64-6. 
churches, showing that the anti-Judaism that the church developed became a theological device, completely divorced from the social reality of Christians, since no Jews lived in Norway at this time. ${ }^{3}$

The intense violence of these images was mirrored also in sermons, unsurprisingly resulting in real-life persecutions of Jews in Europe and creating a pervasive culture of contempt for the Jewish 'other'. This culture of contempt was, in turn, pregnant with the destruction of apocalyptic proportions that was unleashed during the Second World War: the Holocaust. How could this happen? How do we explain these developments, from a Jesus who proclaims a kingdom of heaven in synagogues on Sabbaths, to a church which, on Sundays, defines its life and future as requiring the death of this same synagogue?

In this article, I aim to answer such questions through a historical journey back to the first five centuries of the Common Era, the period which, I believe, holds the key needed to grasp how one thing could lead to another, and why. We shall proceed in three steps. First, we need to define what a 'synagogue' was in the first century, since in some respects ancient synagogues do not have much in common with what we mean by 'synagogue' today. Second, we shall trace what happened with the Jesus movement as it became increasingly defined by its nonJewish members, and place these developments within the context of other contemporary Graeco-Roman cults. Finally, we shall aim the spotlight at one particular place, Capernaum, where archaeological remains have revealed a local example of these broader developments in the Roman Empire.

3 On the Norwegian context, see Aavitsland 2016, analysing the crucifixion scene in the Ål stave church.

\section{From shared institutions to isolated groups}

As is well known, the New Testament repeatedly states that Jesus and his followers attended synagogues on Sabbaths, and in that setting proclaimed that the kingdom of God was near. ${ }^{4}$ But what was a synagogue in the first century? I believe that in the answer to this question lies a key to what happened between the Jesus movement and other Jews, and how later Jews and Christians became estranged from one another. Today, when we speak of a synagogue we mean a religious institution, and the building in which Jews come together for religious services. In antiquity, things were quite different.

Behind what we translate into English with one single word as 'synagogue' lie hidden in the ancient texts no less than seventeen Greek terms, five Hebrew terms and three Latin terms. ${ }^{5}$ The most common of these terms were the Greek proseuche (prayer hall) and synagōgē ('gathering' or 'gathering place'). Ekklēsia, which is today commonly and problematically translated as 'church', was in fact another such term used by Jews for what we would call a 'synagogue. ${ }^{6}$ What is more important, however, is that these terms were used interchangeably for two types of institution. ${ }^{7}$ The first of these was the village or town assembly, a kind of municipal institution in which people came together to make decisions regarding local affairs. ${ }^{8} \mathrm{~A}$ city hall of sorts.

4 See e.g. Matt. 4:23; Mark 1:39; Luke 4:44; John 18:20.

5 For sources, consult the index in Runesson et al. 2008.

6 See the comprehensive study of the term by Korner 2017.

7 For in depth discussion of this, as related to the issue of the origins of the synagogue, see Runesson 2001.

8 See Levine 2005 and Binder 1999 for discussion of activities taking place in and officials in charge of these institutions. 


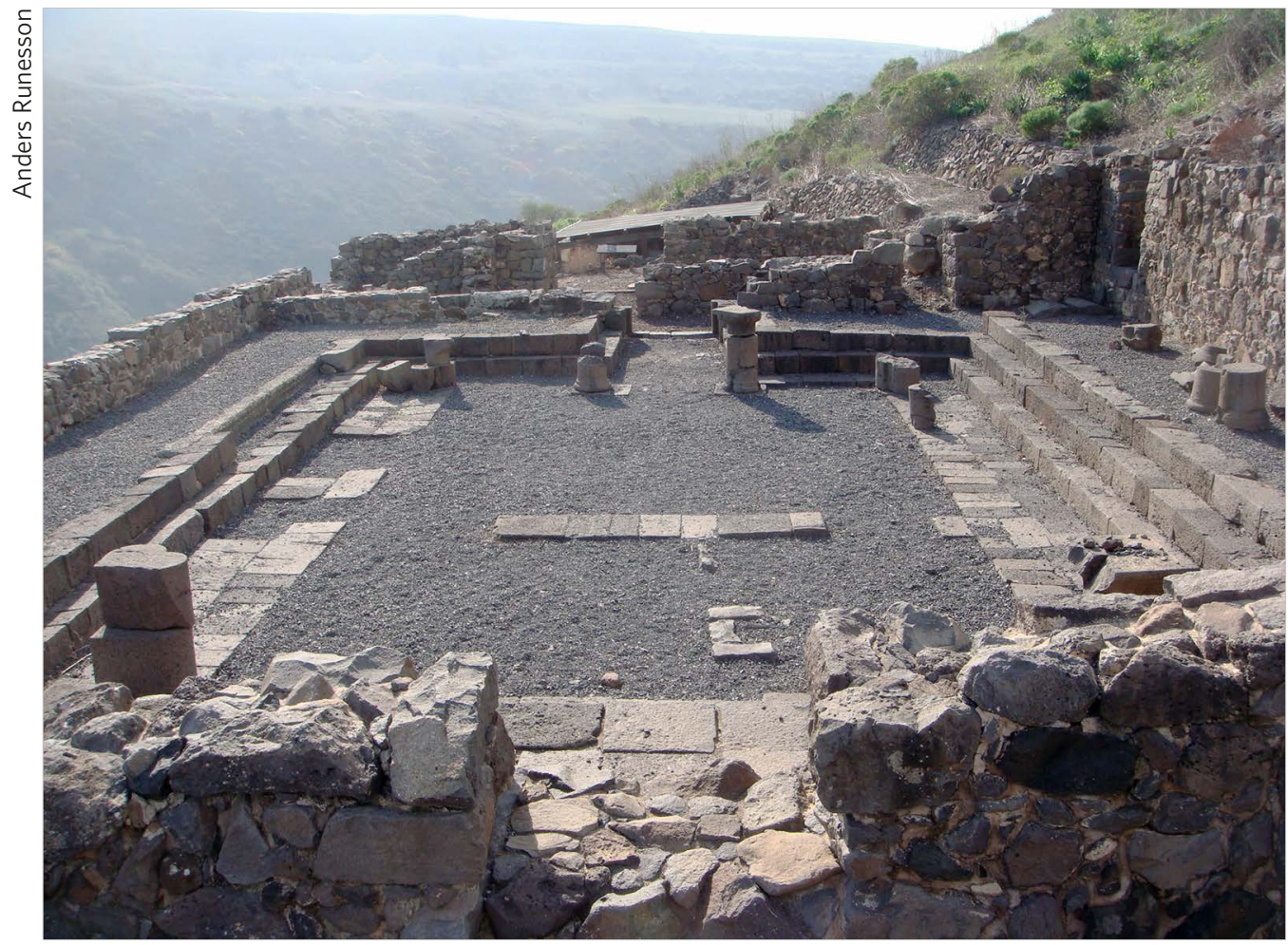

The Gamla synagogue, the Golan Heights, looking south-west, 2009.

Archives were kept there and judicial matters were taken care of in this space, the seat of local government. Also, since religion was not thought of as separate from other spheres of society, including politics, Torah was read and discussed on Sabbaths. No specific Jewish group, such as the Pharisees, were in charge of these public synagogues. Public synagogues were open to all, including women, and the architecture of the buildings indicates that discussions and debates were part of normal procedure. Some groups used the public synagogues as a platform for proclaiming their own version of Judaism; Jesus and his followers did this. ${ }^{9}$

9 See note 4 above, and esp. John 18:20: 'I have spoken openly to the world; I have always taught in synagogues and in the
The other type of institution that was designated by the same synagogue terms was a kind of association, very similar to other such associations in the GraecoRoman world. ${ }^{10}$ Jewish 'association synagogues' were institutions initiated and run by Jews belonging to specific groups, such as the Essenes or the Pharisees. These institutions were not public, but for members only, and their guests. The first-century Jewish author Philo calls the Essenes'

temple, where all the Jews come together. I have said nothing in secret.'

10 See especially the work on associations by John Kloppenborg (2019), and Philip Harland and Richard Last (Harland and Last 2020). See also the recent debate between Richard Ascough $(2015,2017)$, Eric Gruen (2016) and Ralph Korner (2015, 2017a, 2017 b) in Journal of Jesus Movement in its Jewish Setting. 


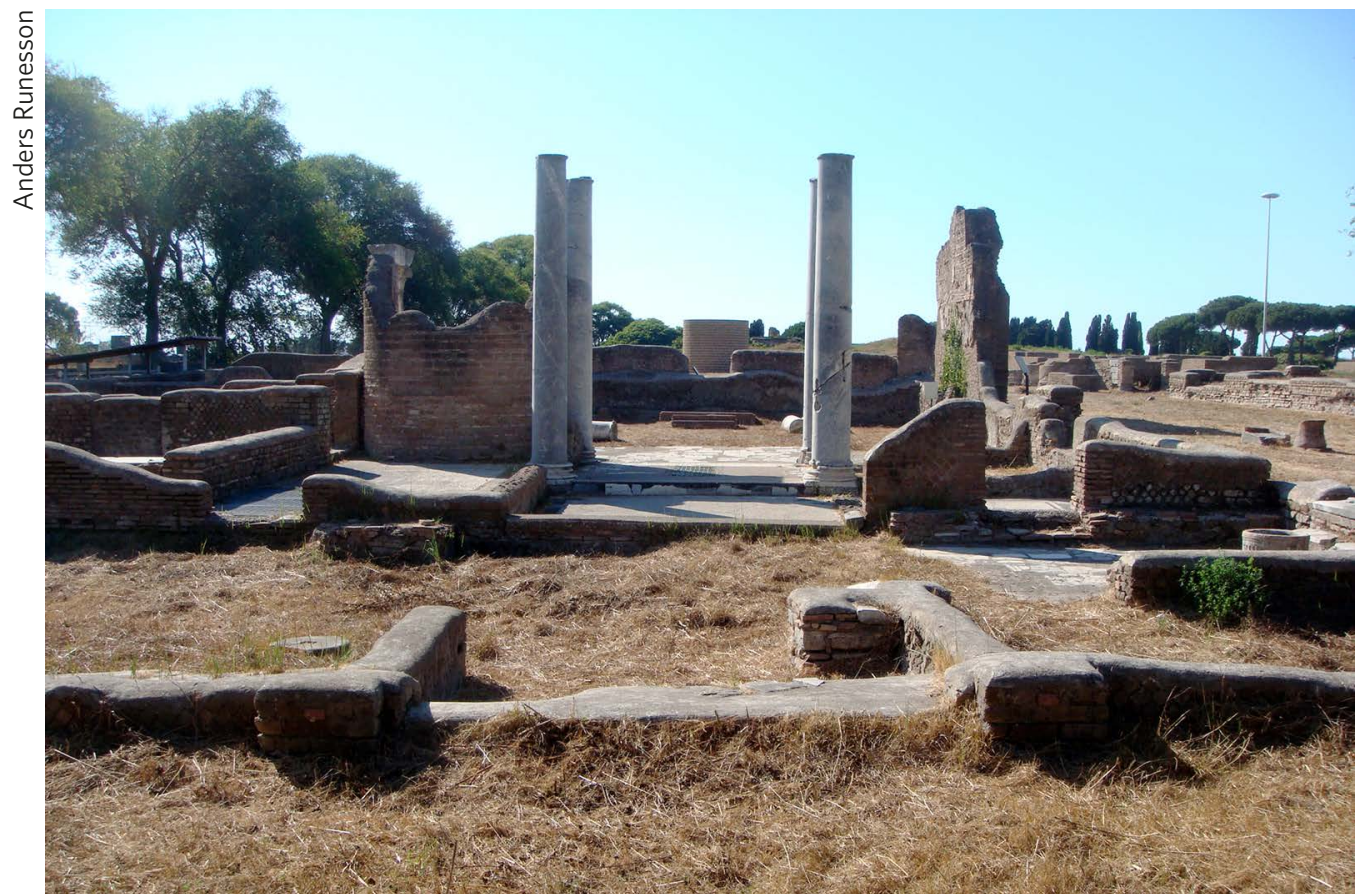

The Jewish association building at Ostia (the Ostia synagogue), 2008.

association a synagōge, 11 and we hear of a 'synagogue of the Freedmen' in Acts 6:9. We also have a first-century inscription from Jerusalem mentioning a synagōgē built by a priest named Theodotos and his father and grandfather, the latter of whom laid the foundation of the building: the Theodotos inscription. ${ }^{12}$

In other words, while most Jews, except for sectarians such as those who authored and used the sectarian writings at Qumran, came together in public synagogues to make local decisions and read Torah on Sabbaths, some groups of Jews also had their own association synagogues in which they interpreted Jewish life as relevant to them, sometimes in unusual and quite specific

11 Philo, Quod omnis probus liber sit 80-3 (Runesson et al. 2008: no. 40).

12 Corpus inscriptionum Judaicarum 2.1404 (Suppelementum Epigraphicum Graecum 8.170); Runesson et al. 2008: no. 26. ways. The Pharisees and the Jesus movement organized themselves in this way too. ${ }^{13}$ While, as far as we know, the historical Jesus never belonged to an association, and never initiated a new formal association himself (he proclaimed and performed his message mostly in public), his followers did so after his death. The Pharisees had their associations, therefore, and now Jesus's followers began forming their own in the midto late first century. This meant the creation of new leadership positions and the establishment of community rules within these Messianic associations. ${ }^{14}$ This means that,

13 The Didache likely represents an association rule for like-minded Jesus groups, and in the Gospel of Matthew we see some traces of a penal code in Matt. 18:15-20. Paul's letters are, in turn, directed to such associations in the Diaspora. On Christ groups as associations, see most recently Kloppenborg 2019. 
if we look at this type of synagogue institution at this time, the Pharisees had their leaders and community rules, and Christfollowers had theirs. These institutions, these associations, were thus independent of each other from the very beginning. Both groups of Jews would, however, still meet in public village assemblies, in public synagogues, and in this shared space they would debate their differences and try to convince one another - and others, since their aim was to reach all Israel with their version of Judaism.

As we know from history, Christfollowers spread rapidly all over the Mediterranean world in the second century onwards, first and foremost in places where Jews already lived, and where there were synagogues (Jewish associations). In these diaspora synagogues they would communicate their message about Jesus and the Kingdom to their fellow Jews as well as to those non-Jews who were often also present, as they were interested in Judaism; these are often called God-fearers in the literature. ${ }^{15}$ As these Jesus-believing Jews (Paul and others) communicated their message, they began organizing themselves as associations, gathering either in private homes or as subgroups within existing synagogues, if other Jews allowed them to do so. In the early second century, however, major cultural changes take place which changed the course of history. In order to describe this development, we need to widen the perspective and take a look at the larger Graeco-Roman world.

14 See note 12 above for some examples.

15 For discussion, see Paula Fredriksen 2016: 25-34.
De-ethnicizing cults in the Graeco-Roman world In the Graeco-Roman world, many cults originated from specific places, such as the Isis cult from Egypt. Around these cults formed what we would call associations, whose key purpose was to honour their god. ${ }^{16}$ Originally, the adherents of these cults came from specific ethnic groups, since in antiquity, what we call 'religion' was thought of as closely connected with specific ethnic identities and laws, so that we see a close relationship between a people, a land, a law and a god. ${ }^{17}$ In other words, if you were from a specific ethnic group, you worshiped a specific god, and had no problem with the fact that other ethnic groups worshipped their own gods. This was so also for the Jewish people: the Jews, just as everybody else, had their own land and their own law, and worshipped their own specific god, the God of Israel - and they did so in the Diaspora too.

At some point, however, many GraecoRoman cultic associations began to attract worshippers from other ethnicities. The Isis cult, for example, grew to become extremely popular around the Mediterranean, and non-Egyptians began to worship Isis too. The ethnic identity of those who worshipped Isis thus became mixed, to the degree that Egyptians were soon a minority in such cultic settings. It is interesting to note that this is precisely what we see happening with the Jewish synagogues in the Diaspora, already before believers in Jesus arrive on the scene of history. When the Jesus movement starts to spread, however,

16 To be sure, there were also other types of associations, such as occupational or neighbourhood associations, whose purpose was to support various forms of networks, but all of which had their own patron god.

17 See Mason 2007: 457-512. 
this phenomenon takes on new proportions. Soon, the Christ-followers begin to establish their own Messianic associations, with a mix of Jewish and non-Jewish members. Paul's letters and the Acts of the Apostles deal extensively with the issue of how exactly these non-Jews are to be received in the Messianic synagogues. While there were different views in the early movement, the majority eventually decided that non-Jews could be full members of these Christ-groups without converting to Judaism. There is no fear yet that the Jewishness of the movement would be threatened by such a decision, but the decision does lead to a break with many other Jewish associations. ${ }^{18}$ In the second century, though, and Ignatius of Antioch is our first witness to this development, ${ }^{19}$ these non-Jewish members of the Messianic synagogues would no longer accept ethnicity as a meaningful category at all, just as some other Graeco-Roman cults, the Isis cult included, had already lost their ethnic identity markers in relation to their membership.

For these non-Jews, it would no longer be acceptable to claim that religio-ethnic Jewish status was compatible with belief in Jesus as the Christ. Ignatius says it

18 Cf. e.g. Acts 15:1-21. Since these Jewish Messianic associations were interested in non-Jews for theological reasons (the end of time was getting closer and gentiles were expected to join them), many non-Jews became members as a result of missionary efforts. Acts 15 deals with how to handle such non-Jewish members, without losing sight of the fact that the heart of this Messianic movement was Jewish. Paul does the same thing in Romans 11.

19 See e.g. Ignatius, Epistle to the Magnesians 10.1-3 (cf. Epistle to the Philadelphians 6.1), where a clear distinction is drawn between christianismos (the first time this word is used) and ioudaismos. outright: you cannot practise Judaism and be a 'Christian' at the same time. ${ }^{20}$ These non-Jewish Christ-followers thus divorced themselves from Jewish Christ-followers, who maintained their Jewish identity as a vital component of their religious identity, just as Jesus and the earliest disciples had done. ${ }^{21}$ With Ignatius we find, then, in this respect, the beginning of the process which led to the establishment of 'the church' as we know it today - a distinct, non-Jewish 'religious' institution. This new development in the second century led to a rising popularity of Christ-belief/Christianity, as disconnected from Judaism. It was this form of non-Jewish Christianity that found its way into the leading strata of Roman society and eventually to the emperor himself, Constantine. It was this form of Christ-belief that became 'state religion' in the Roman Empire under Theodosius I in the late fourth century. And it was this form of Christianity that eventually spread all over the world, so that it is now the world's largest religion. ${ }^{22}$ Jewish Christbelievers and non-Jewish Christ-believers no longer gathered in the same association synagogues, but had parted ways with each other. A 'Christian' could no longer, according to these groups, also be Jewish.

It is interesting to note, however, that this development was driven, sometimes forced, by the Christian elite. Indeed, as late as in the time of Chrysostom, in the late fourth century, we have evidence that grass-roots Christians saw little difference between Christianity and Judaism, and attended both church and synagogue interchangeably. This explains why Chrysostom's sermons could turn so

20 Ignatius, Epistle to the Magnesians 10.3.

21 On this process, see also Zetterholm 2003.

22 See the report by PEW Research Center (Hackett and McClendon 2017). 
fiercely anti-Jewish - his purpose was to deter his congregants from attending synagogue. ${ }^{23}$ The so-called 'parting of the ways' was thus to a large degree a programme primarily nurtured and implemented by the church elite, not the people. ${ }^{24}$ It should also be emphasized that this so-called parting of ways was not between 'Judaism' more generally and 'Christianity' more generally, as is also clear from the types of institutions we discussed above, but something that happened within the Jesus movement. The question that remains to ask is, therefore: what happened with the Jewish followers of Jesus, from whom these non-Jewish Christians divorced themselves? ${ }^{25}$

Jewish believers in Jesus: what happened?

As noted above, developments in and between Christ-groups and their associations in the second century led to the emergence of what we today identify as the church. But what happened to the Jewish followers of Jesus? Could they, for example, remain within the public synagogues in Palestine, and still maintain their own associations alongside other Jewish associations? The answer seems to be yes; they did, for several centuries, but not without conflict with other Jews (and non-Jews). A brief overview of the situation in Palestine will shed further light on the fate of these Jewish believers in Jesus.

23 The homilies are found at Patrologia Graeca XLVIII, cols. 843-942. For discussion of Chrysostom, see Murray 2004.

24 Cf. from a different perspective, Smith 2018.

25 Cf. Porter and Pearson 2000: 82-119, here p. 114: 'The real question should not be "Why did Jews and Christians split?", but rather, "Whatever happened to Jewish Christianity?"”
The combination of public village synagogues and association synagogues remained in place as long as the Jews controlled their own towns and villages. However, when the Emperor Constantine and his mother Helena in the fourth century, and later Christian emperors, began colonizing the land, aiming to turn it into a Christian Holy land, this all changed. Since public synagogues were municipal institutions in charge of administration, they were rendered obsolete when Byzantine Christians took over the administration in many places. This pattern then continued under Muslim rule. What was left then, when the public synagogues lost their function, was the association synagogues of specific Jewish groups. These synagogues now provided people with a place to read Torah together and worship, but they were not related to the civic administration of the towns and villages ruled by (non-Jewish) Christians. Interestingly, it was around this time that the rabbis began to become the dominant group in Jewish society. The rise of rabbinic Judaism as mainstream Judaism is thus connected to a process in which Jews lost their shared public/political space. Or, seen from a different perspective, the rabbis were part of transforming Jewish society and defining Jewishness at this time, as their way of being Jewish became influential among Jews in the towns and cities of Palestine. One could perhaps say that this process transformed the 'synagogue' into the type of Jewish religious institution we see today, whose institutional roots lie in the Jewish associations.

Since rabbinic Judaism represented a specific form of Judaism and the synagogues they were influential in were dedicated to this form of Judaism, Jews who joined them had to adhere to this specific form of Jewish belief and practice. 
Consequently, and simply put, Jews who understood Jesus as the Messiah had no shared space in which to express their identity, since 'synagogue' was now defined as 'rabbinic synagogue', and public synagogues, the administrative centres of towns and cities previously run by Jews, had vanished. When people talked about 'the synagogue' at this time, around the fourth or fifth century, what they meant was almost always 'rabbinic Judaism/synagogues'.

Jewish followers of Jesus now had to meet in their own associations only, and became increasingly marginalized between growing rabbinic Judaism on the one hand, and the rise of non-Jewish Christianity on the other. We hear of Jewish forms of Christ-belief as late as in the fourth century, but then most traces of them disappear into the shadows of history. With their disappearance the scene is set for the developments that led to the present-day situation, with no shared space between Jewish Jesus followers and other Jews, and two religious institutions, for Jews and (nonJewish) Christians, nurturing distinct identities. Again, we should note that in this overall historical reconstruction, there was no so-called parting of the ways between 'Judaism' and 'Christianity' as general categories. The parting that took place was, as we have mentioned, between Jewish and non-Jewish believers in Jesus. Rabbinic Judaism, the mother of all modern mainstream forms of Judaism, had only a secondary role in these developments.

As it happens, the historical pattern that we have just summarized in more general terms seems to have left marks in the archaeological remains of one specific place: Capernaum. In late antiquity, Capernaum boasted both a synagogue and a church, built very close to one another. While the buildings we see today were constructed in the fifth century CE, interestingly, digging beneath them reveals earlier structures going back to the first century. I have described the histories of these buildings elsewhere, and will therefore only summarize here the general picture that emerges from an analysis of the archaeological remains, referring the interested reader to the more detailed discussion in that study. ${ }^{26}$

Visitors to Capernaum today will see and likely be impressed by the large white limestone synagogue, which dates back to the fifth century CE. But underneath this synagogue, the excavators, Virgilio Corbo and Stanislao Loffreda, found the remains of a first-century structure, constructed in local black basalt stone. While we cannot go into detail here, and the claims by the excavators are still debated, the history of the synagogue(s) at Capernaum may be reconstructed as follows. In the first century a synagogue was constructed of black basalt stone. If this is correct, it is reasonable to assume that this structure would be the public synagogue Jesus is said to have attended on the Sabbath, according to the New Testament Gospels. Then, between the second and fourth centuries, this synagogue was renovated and enlarged. In the fifth century, the black basalt synagogue was destroyed and the monumental white limestone synagogue we see today was constructed, partly using the remains of the basalt synagogue as a foundation.

Interestingly, about thirty metres south of the synagogue the remains of an octagonal Byzantine church were found, constructed in the fifth century. The proximity of the synagogue and the church has puzzled scholars ever since the discovery of these buildings. How was it possible for a church to be constructed so close to

Runesson 2007: 231-57. 
a synagogue, at this time in history? But it gets even more interesting, as the excavators found, below the Byzantine church, remains of earlier churches. In fact, the octagonal Byzantine church replaced what was an earlier house-church, or perhaps better: house synagogue, dating to the fourth century. This house-church, in turn, was built around an older private house in which one of the rooms was set aside for worship already in the late first century. This house has been identified by the excavators as the house of Peter. In other words, if they are correct, followers of Jesus gathered in this place over a long period of time, from the late first century until the later octagonal church was abandoned. ${ }^{27}$

Now, if we compare the dates of the synagogue(s) and the gathering place for Jesus's followers, we find an interesting pattern, which signals co-existence of Jews and Christ-believers from the first to the sixth centuries in a small Galilean town. But how are we to understand this co-existence? Was it friendly? Or was it one of competition and conflict?

The historical reconstruction I have proposed unfolds as follows. In the first century, Jews gathered in the black basalt synagogue, which was a public synagogue. This was the synagogue which both Jesus and his followers attended, together with other Jews. Towards the end of the first century, the so-called House of Peter had become a meeting place for those who believed that Jesus was the Messiah. Graffiti and renovations from the late first and the second centuries confirm the identification. Such a gathering place is, in my view, best described as a Jewish association, an association synagogue, for Jewish believers

27 For an accessible presentation of the excavation results, see Loffreda 1997. in Jesus. These Christ-followers thus gathered in two places: in public space shared with other Jews, and in their own association thirty metres south of the public synagogue. At this time, Capernaum was a Jewish town. In the fourth century, an earthquake hit the area. The private house that had functioned as a gathering place for Jesus followers was turned into a more formal house-church/synagogue, with a wall constructed around it. The physical centre of this Christ association was still the same room in which the earlier Jewish Christ-believers had gathered. While pilgrims now came in from other parts of the Mediterranean world, the Christ-believers here were still mainly of Jewish origin. And the town was still Jewish. ${ }^{28}$

Then something very drastic happened in the fifth century. The house church was torn down, and a new octagonal church was constructed. This church was undoubtedly built by non-Jewish Christians. The Jewish Christ-followers now seem to disappear from the history of this place. The town of Capernaum expands, and remains of non-Jewish buildings and other artefacts abound from this period. Capernaum had

28 Cf. Epiphanius, who claims that Capernaum was Jewish (which does not exclude the presence of Jewish followers of Jesus, as we know from the Mishnah, the minim, or 'heretics') until the fourth century: 'Josephus [a Jewish believer in Jesus] asked only this very great favor from the emperor - permission by imperial rescript to build Christ's churches in the Jewish towns and villages where no one had ever been able to found churches, since there are no Greeks, Samaritans or Christians among the population. This "rule" of having no gentiles among them is observed especially at Tiberias, Diocaesarea, Sepphoris, Nazareth and Capernaum' (Epiphanius, Panarion 30.11.9-10; English translation by Williams 1987). 
become primarily a non-Jewish Christian pilgrimage town, and, accordingly, administration was now in the hands of non-Jews.

At about the same time the limestone synagogue was constructed, probably with the help of the affluent and more powerful Jews of nearby Tiberias. But this synagogue could not have functioned as a public administrative institution, since the town was now in the hands of gentile Christians. Interestingly, the building largely adheres to rabbinic norms in terms of its decoration, avoiding art displaying humans, or the zodiac, which we find in some other synagogues from this time. The likelihood is, then, that the Jewish community refused to disappear from Capernaum, claimed their space in this town, and rebuilt/constructed a synagogue. But when rabbinic Judaism controlled this synagogue, which seems likely, and no Jewish civic space (public synagogue) existed in this town any more, it also meant that there was no longer any public Jewish gathering space for Jewish believers in Jesus in Capernaum. In addition, the non-Jewish Christians had taken over the so-called House of Peter and constructed a new building in its place. What was once a Jewish small town, the headquarters of Jesus and his disciples, had now become the battleground of two emerging world religions: non-Jewish Christianity and Rabbinic Judaism.

\section{Conclusion: the past in the present}

So, what are we to conclude, finally, from all of this? Perhaps one of the key insights is that neither theology nor history is inevitable; they are made, not begotten, formed by people of flesh and blood. Studying the origins of Christianity and Judaism through the lens of the institutional realities within which interaction between followers of Jesus and other Jews and nonJews was defined reveals that what to many have appeared as theologically necessary developments, in reality are processes in which threads of social, political, and colonial decision-making are intertwined. What we think and do, how we perceive ourselves and others, is more often than not the result of what other people before us have decided, what they have chosen as the 'right path'. In order to locate our own position beyond 'theological determinism', we need to study the mechanisms that influence historical developments, and in that process also feel free to contemplate the fact that we are not imprisoned by the past, but are at liberty to consider a better future based on whatever we may learn.

If we do, centuries of hostile history can be overturned, as cultural change takes place and visions of a different tomorrow begin to grow. Historical processes led to the creation not only of distinct Jewish and Christian identities, but also resulted in increased polarization and violence between religions as Christianity created a culture of contempt for Jews and Judaism. These historical processes were made possible partly because of the loss of shared space; space where people of different views and backgrounds could actually meet, face to face, and discuss and debate. This lost space, the 'public synagogue, cannot, of course, be re-created, but history invites us to consider what kind of shared spaces we do have access to in our own societies today, where we can meet, discuss, debate and learn from one another, from those who are not like us; from those who think differently. It seems to me that one of the most important such open, shared and indeed international spaces is the university; the academy, representing 'neutral ground' where knowledge is formed in open conversation and debate as people of different backgrounds establish researchbased discourses that enrich society. 
In terms of Jewish-Christian relations, it took until the Second Vatican Council in the 1960 s before Christian anti-Jewishness was seriously challenged at an institutional level and developments began to be reversed. The first ever papal visit to a synagogue took place as late as in 1986, when Pope John Paul II met Rabbi Elio Toaff. John Paul II's successor, Pope Benedict, followed in his predecessor's footsteps, as did Pope Francis, crossing the River Tiber in Rome to visit the Great Synagogue. The significance of such visits, even if symbolic, can hardly be overestimated. While there were many factors involved which made the 1986 papal visit to the Great Synagogue possible, research has shown that biblical studies have had a significant impact on how churches have re-evaluated their relationship with the Jewish people, and how they have legitimized a dialogical posture of friendship and a shared sense of purpose. ${ }^{29}$ In the same way, scholars and rabbis representing Jewish communities have also formulated documents envisioning a friendship between Jews and Christians that has not been possible for centuries. ${ }^{30}$

We must never forget, though, that the kind of shared space that the university represents is not a given. Academic freedom, which is a sine qua non for the entire academic project, has been and is currently under attack in many parts of the world, including in the Nordic countries. Such freedom must be cherished, nurtured and protected. At the university, old truths are questioned and new insights grow as we debate our way to conclusions that were

29 See discussion in Runesson 2013.

30 One example is the often referenced document 'Dabru Emet (Speak truth): a Jewish statement on Christians and Christianity', published in The New York Times on 10.9.2000. beyond the reach of our predecessors - and which will again be challenged when we are no longer here. The freedom to seek understanding without constraints is a privilege, and, indeed, crucial to the project of studying religion when it develops and morphs as part of the larger cultural changes in society that continue to shape the way we see the world and ourselves. We, as academics, are part of these cultural changes that we study, and this, too, in my view, is a good thing.

Anders Runesson, Ph.D. (Lund University), is Professor of the New Testament at the University of Oslo. He has authored and edited eleven books and published more than sixty articles spanning the field of the New Testament, Jewish history

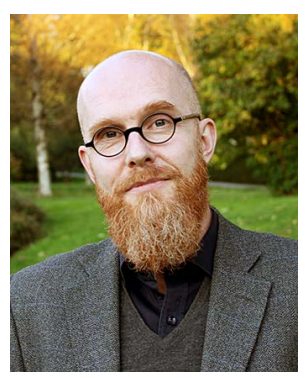
and, specifically, the intersection between Jewish and Christian traditions. Publications include two award-winning monographs: The Origins of the Synagogue: A Socio-historical Study (Almqvist \& Wiksell International 2001), and Divine Wrath and Judgment in Matthew: The Narrative World of the First Gospel (Fortress Press 2016). His most recent book is Jesus, the New Testament, and Christian Origins: Perspectives, Methods, Meanings (Eerdmans 2021), which he co-edited with Dieter Mitternacht.

\section{Bibliography}

Aavitsland, Kristin B. 2016. 'The church and the synagogue in ecclesiastical art: a case from medieval Norway', Teologisk tidskrift 5(4): 324-41.

Ascough, Richard. 2015. 'Paul, synagogues, and associations: reframing the question of models for Pauline Christ groups, Journal of the Jesus Movement in its Jewish Setting 2: 27-52, <http://www.jjmjs.org/ uploads/1/1/9/o/11908749/ascough_paul_ synagogues_and_associations.pdf $>$.

Ascough, Richard. 2017. 'Methodological reflections on synagogues and Christ groups as "associations": a response to Eric 
Gruen', Journal of the Jesus Movement in its Jewish Setting 4: 118-26, <http://www.jjmjs. org/uploads/1/1/9/o/11908749/ascough_-_ methodological_reflections.pdf $>$.

Binder, Donald D. 1999. The Place of the Synagogues in the Second Temple Period, SBL Dissertation Series 169 (Atlanta: Society of Biblical Literature).

'Dabru Emet: a Jewish statement on Christians and Christianity', The New York Times 10.9.2000, p. 23, New England edition, <https://www.bc.edu/content/dam/ files/research_sites/cjl/texts/cjrelations/ resources/documents/jewish/dabru_emet. htm>.

Fredriksen, Paula. 2016. 'If it looks like a duck, and it quacks like a duck...: on not giving up the godfearers', in A Most Reliable Witness. Essays in Honor of Ross Shepard Kraemer, eds. Susan Ashbrook Harvey et al. (Providence, RI: Brown Judaic Series), 25-34.

Gruen, Eric. 2016. 'Synagogues and voluntary associations as institutional models: a response to Richard Ascough and Ralph Korner', Journal of the Jesus Movement in its Jewish Setting 3: 125-31, <http://www.jjmjs. org/uploads/1/1/9/o/11908749/jjmjs-3_ gruen.pdf>.

Hackett, Conrad, and David McClendon. 2017. 'Christians remain world's largest religious group, but they are declining in Europe, PEW Research Center 5.4.2017, <https://www.pewresearch.org/ fact-tank/2017/04/05/christians-remainworlds-largest-religious-group-but-theyare-declining-in-europe/>.

Kloppenborg, John S. 2019. Christ's Associations: Connecting and Belonging in the Ancient City (New Haven, CT: Yale University Press).

Korner, Ralph. 2015. 'Ekklēsia as a Jewish synagogue term: some implications for Paul's socio-religious location', Journal of the Jesus Movement in its Jewish Setting 2: 53-78, <http://www.jjmjs. org/uploads/1/1/9/o/11908749/korner ekkl\%C4\%93sia_as_a_jewish_synagogue_ term.pdf>.

Korner, Ralph. 2017a. 'Ekklēsia as a Jewish synagogue term: a response to Eric Gruen', Journal of the Jesus Movement in its Jewish Setting 4: 127-36, <http://www.jjmjs.org/ uploads/1/1/9/o/11908749/korner_-_ekklesia_as_a_jewish_synagogue_term.pdf $>$.

Korner, Ralph J. 2017b. The Origin and Meaning of Ekklēsia in the Early Jesus Movement, Ancient Judaism and Early Christianity 98 (Leiden: Brill).

Last, Richard, and Philip A. Harland. 2020. Group Survival in the Ancient Mediterranean: Rethinking Material Conditions in the Landscape of Jews and Christians (London: T\&T Clark).

Levine, Lee I. 2005. The Ancient Synagogue: The First Thousand Years, 2nd edn (New Haven, CT: Yale University Press).

Loffreda, Stanislao. 1997. Recovering Capharnaum (Jerusalem: Franciscan Printing Press).

Mason, Steve. 2007. 'Jews, Judaeans, Judaizing, Judaism: problems of categorization in ancient history', Journal for the Study of Judaism 38: 457-512.

Murray, Michele. 2004. Playing a Jewish Game: Gentile Christian Judaizing in the First and Second Centuries CE. Studies in Christianity and Judaism 13 (Waterloo, ONT: Wilfrid Laurier University Press).

Porter, Stanley E., and Brooke W. R. Pearson. 2000. 'Why the split? Christians and Jews by the fourth century', Journal of Greco-Roman Christianity and Judaism 1: 82-119.

Runesson, Anders. 2001. The Origins of the Synagogue: A Socio-Historical Study, Coniectanea Biblica, New Testament 37 (Stockholm: Almqvist \& Wiksell International).

Runesson, Anders. 2007. 'Architecture, conflict, and identity formation: Jews and Christians in Capernaum from the 1st to the 6th century', in Religion, Ethnicity and Identity in Ancient Galilee: A Region in Transition, eds. Jürgen Zangenberg, Harold W. Attridge, and Dale Martin, Wissenschaftlichen Untersuchungen zum Neuen Testament 210 (Tübingen: Mohr Siebeck), 231-57.

Runesson, Anders. 2013. 'Judging the theological tree by its fruit: the use of the Gospels of Mark and Matthew in official church documents on Jewish-Christian relations', in Mark and Matthew. Comparative Readings II: Hermeneutics, Reception History, Theology, eds. Eve-Marie Becker and Anders Runesson (Tübingen: Mohr Siebeck), 189-228. 
Runesson, Anders, Donald D. Binder, and Birger Olsson. 2008. The Ancient Synagogue From its Origins to $200 \mathrm{CE}$ : A Source Book. Ancient Judaism and Early Christianity 72 (Leiden: Brill).

Schreckenberg, Heinz. 1996. The Jews in Christian Art: An Illustrated History (New York: Continuum).

Smith, Eric C. 2018. Jewish Glass and Christian Stone: A Materialist Mapping of the "Parting of the Ways" (London: Routledge).

Williams, Frank 1987. The Panarion of Epiphanius of Salamis. Book I (Sects1-46), Nag Hammadi Studies 35 (Leiden: Brill).

Zetterholm, Magnus. 2003. The Formation of Christianity in Antioch: A Social-Scientific Approach to the Separation between Judaism and Christianity (London: Routledge). 